\title{
"Forming Partnerships": Extramarital Songs and the Promotion of China's 1950 Marriage Law
}

Levi S. Gibbs

\begin{abstract}
Shortly after a push to promote China's 1950 Marriage Law in 1953, scholars from the Chinese Music Research Institute on a collection trip to a small locality in northern China encountered a large number of folksongs about extramarital affairs. They interpreted this as evidence of the need for marriage reform. The folksong lyrics highlighted controversial aspects of the Marriage Law by espousing one of the law's central tenets - free love while also expressing women's desires to leave their husbands. In this article, I explore how the researchers placed the song lyrics in a liminal moral-temporal category between "feudal" arranged marriage and the new marriage system before declaring the songs to be relics of the victimization of women in a "feudal" past. I argue that additional light-hearted elements complicate the researchers' conclusion and suggest that when the promotion of social agendas in the 1940s and 1950s cast songs about illicit affairs as morally ambiguous, Chinese scholars chose to ascribe the songs' "roots" to other groups or to the "feudal" past of the people they sought to praise and/or transform.
\end{abstract}

Keywords: 1950 Marriage Law; extramarital relations; folksongs; marriage reform; Shanxi; Hequ; China

The Son of Heaven would send officials out every five years to collect songs (shi 诗) in order to observe the customs of the people.

- Book of Rites 礼记 $1^{1}$

Folk music is an art form through which each group of people expresses their own life, thoughts and feelings, so in order to understand folk music, we must first research the life, thoughts and feelings of the labouring people.

— Lü Ji, "Outline for Chinese folk music research"2

Is folklore always in translation? We begin by acknowledging that the study of folklore ... is as much about the folk and their voices as about the story of political authority and historical forces that struggle to make the people legible as such.

- Lydia H. Liu, "Translingual folklore and folklorics in China"

* Dartmouth College. Email: Levi.S.Gibbs@Dartmouth.edu.

1 Cited in Yang, Yinliu 1980, Vol. 1, 190.

2 Lü 2004, 62.

3 Liu, Lydia H. 2012, 190, italics added. 
When researchers from the Chinese Music Research Institute encountered a large number of folksong lyrics about extramarital affairs in 1953 while on a collection trip to a remote county town in northern China, they interpreted the lyrics as evidence of the need for marriage reform. The trip to Hequ 河曲 county, located in north-western Shanxi province on the banks of the Yellow River, followed Zhou Enlai's 周恩来 push to promote China's new 1950 Marriage Law in the spring of 1953, and the lyrics the researchers collected highlighted controversial issues in the Marriage Law. ${ }^{4}$ Both lyrics and law championed free love, but the songs also expressed women's desires to leave their husbands, which would soon be legally possible with the institution of marriage reform. Men at the time feared that the new law, which they referred to as the "divorce law," would deprive them of half of the property they had received from land reform. ${ }^{5}$ While women's desires to pick their own lovers could have been seen as progressive, and lighthearted elements in certain songs about extramarital relations belied a tragic view, the researchers concluded that the behaviour reflected in the songs known locally as "forming partnerships" or "making friends" - was a relic of the historical oppression of women.

The assumption that folksong lyrics mirror society has deep roots in China, while the researchers' attempt to categorize behaviour associated with songs into moral-temporal periods was based on the Marxist historical materialism prevalent at the time. In China and elsewhere, scholars at different points in history have collected, edited, and quoted popular song lyrics as "record[s] of popular consciousness" when seeking to praise or transform rural "imagined communities."6 However, scholars who transcribe song lyrics from a locality to make its people "legible" bring the lyrics into new interpretive frameworks. ${ }^{7}$ In the context of new social agendas in the 1940s and 1950s, Chinese scholars and officials felt compelled to judge the moral content of traditional song lyrics. ${ }^{8}$ For several decades beginning in the early 1950s, anthropologists and folklorists in mainland China followed the principle of "transforming social traditions" (yifengyisu 移风易俗). Yang $\mathrm{Mu}$ describes how these “scholars should not just study social customs, they should also follow government guidelines to distinguish 'bad' customs from 'good' ones, and work to eliminate the 'bad' ones from the society." "Bad" customs in such a context became associated with the "feudal" past, while "good" practices were to remain in the present and future. While the principle's goal was to ensure a morally homogenous nation, when researchers encountered local customs that problematized romantic notions of the people's purity, they had to explain those customs in a way that maintained the people's overall integrity.

6 Frith 2007, 218; Anderson 1991; cf. Wilson 1973; Harker 1985; Filene 2000.

7 Liu, Lydia H. 2012, 191; Scott 1998; Fine 1984, 89.

8 Bauman and Briggs 1990, 61.

9 Yang, Mu 1994, 113. 
When the Beijing-based scholars from the Chinese Music Research Institute found behaviour in a peripheral portion of the People's Republic that contradicted prevailing notions of the people's purity - behaviour the scholars considered to be morally ambiguous - they had to decide whether to blame the behaviour on outside influences or to praise the behaviour as emanating from the people. In doing so, the researchers needed to conceptualize the behaviour either as part of the pre-1949 past or part of the post-1949 future. Since moral judgements implicitly raise one group above another, and because Hequ county was part of the People's Republic of China, rather than judging Hequ's extramarital behaviour as emanating from a geographical "other," the researchers chose instead to associate that behaviour with the past - the temporal "other" of the present. They thus placed Hequ, a region that had yet to implement marriage reform, in a liminal temporality - geographically part of the People's Republic but still in the process of social reform.

In this article, I explore how the researchers placed local Hequ song lyrics about extramarital affairs into a moral-temporal category between "feudal" arranged marriage and the new marriage system. I argue that additional lighthearted elements in lyrics complicate the researchers' conclusion that the songs were relics of a "feudal" past that reflected the victimization of women. I suggest that when the promotion of social agendas in the 1940s and 1950s cast songs about illicit affairs as morally ambiguous, Chinese scholars chose to ascribe the songs" "roots" to other groups or the "feudal" past of the people they sought to praise and/or transform.

\section{Historical Ties between Folksong Collection and Social Analysis}

In China and many other cultures in the world, the collection of folksongs has provided a point of contact between peripheral populaces and a central elite. For example, in 18th and 19th-century Germany, the writings of Johann Gottfried von Herder (1744-1803) and the brothers Grimm inspired romantic nationalistic views of "folksong as a spontaneous, autochthonous expression of the 'collective soul' of the people." 10 In mainland China in the 1920s, in turn, one scholar referred to folksong as "the crystallization of the national spirit." 11 In each case, scholars essentialized particular groups by writing down their folksongs.

Folksong collection in China has a history of over two thousand years. ${ }^{12}$ "In imperial China," notes Lydia H. Liu, "it was the political authority associated with the power of writing that made folklore legible to the imperial eye and available to posterity." ${ }^{13}$ Scholars and officials seeking to represent rural populaces

10 Wilgus 1959, 4.

11 Cited in Hung 1985, 17.

12 For an excellent introduction to the history of folksong studies in China, see Schimmelpenninck 1997, 1-15.

13 Liu, Lydia H. 2012, 191; cf. Scott 1998. 
during various periods of Chinese history have transcribed and interpreted folksong lyrics. Examples include The Book of Songs, the Han dynasty Music Bureau (Yuefu 乐府), Feng Menglong's 冯梦龙 Ming dynasty Mountain Songs (Shan'ge 山歌), the May Fourth-era journal Folksong Weekly (Geyao zhoukan 歌谣周刊), and the 1956 Hequ Folksongs: A Collection of Investigations and Research, examined below. In many cases, scholars presented transcribed folksong lyrics as embodiments of an anonymous vox populi, sometimes using lyrics as evidence in social critiques.

The Chinese term for "collecting folksongs" (caifeng 采风), as Yang Yinliu points out in his history of ancient Chinese music, can be interpreted as an abbreviated version of the phrase, "to gather social customs" (caifang fengsu 采访风 俗). ${ }^{14}$ The Book of Rituals ( $L i j i$ 礼记), which deals with the social forms, government and ceremonial rites of the Zhou Dynasty (c. 1050-256 BCE), records that the emperor would send out officials every five years to collect songs to observe the customs of the people. ${ }^{15}$ Sue Tuohy notes, "it is written repeatedly that Confucius (551-479 B.C.E.) could discern a state's character by hearing its music." 16

The idea of using folksongs as a form of social evidence is poignantly evoked in a story from the Zuo Commentary (Zuozhuan 左传) in which Duke Zha (Ji Zha 季札, fl. 512 BCE) intuits the "conditions of governance and popular sentiment" of several kingdoms by observing performances of songs from the "Airs of the kingdoms" (Guofeng 国风) section of The Book of Songs..$^{17}$ In the story, Duke Zha uses folksongs as moral gauges for the populaces of these kingdoms - a "barometer of the spiritual condition of the people" whereby "poems of excess signify moral decay and sociopolitical disintegration." 18 At times, however, the Duke appears to use songs as rhetorical support for his own preconceived notions. For example, hearing the songs of the kingdom of Wei, Duke Zha exclaims, "Beautiful! Profound! They are grave but not despondent. I heard that the virtues of Kangshu of Wei and Duke Wei are like these airs of Wei." Clearly, he conflates song and virtue. ${ }^{19}$ When the Duke hears the songs of the state of Zheng, he says, "They have gone too far in elaboration. The people cannot endure, and the state of Zheng will be the first to perish." ${ }^{20}$ In both cases, the Duke produces moral judgements from songs which he then uses to reinforce narratives of economic prosperity or social decline.

During various periods of Chinese history, scholars often included moral analyses of folksongs in arguments where essentialized notions of the folk proved useful. In the Ming dynasty, Feng Menglong contrasted the "true feeling" (zhenqing

17 Cai 2002, 40. For a translation of the story, see ibid., 41-42.

18 DeWoskin 1982, 29; Cai 2010, 105.

19 Translated in Cai 2002, 41.

20 Ibid. 
真情) of local folksongs with the "phoniness" of elite poetry - two generic categories he rhetorically connected to the "Airs" and the "Great odes" in The Book of Songs. ${ }^{21}$ In Feng's "Preface to Mountain Songs," he wrote, "Although in our era of decline there is an abundance of false poetry and prose, there are no false folk songs." 22 Feng's rhetorical use of folk culture bears a certain similarity with that of Herder. Benjamin Filene writes, "To Herder, folk culture offered a way to escape the Enlightenment's stifling emphasis on reason, planning, and universalism in cultural expression. Folk forms could cleanse culture of the artificiality that, he felt, was poisoning modern life." ${ }^{33}$ By insisting "[t]he simplest and the most vulgar is also the most genuine," Feng Menglong attempted to subvert moral condemnations of "bawdy" songs, adding his support to contemporary arguments in the Cult of Feeling. ${ }^{24}$ During the May Fourth era in the early 20th century, the inaugural statement of the 1918 Folksong Movement offered similar romanticized, subversive moral views of bawdy songs. In the statement, the editors of Folksong Weekly suggested that "there is no such thing as obscenity or vulgarity in the academic field," and all folksong materials could be considered as contributing to "the voice of the folk." 25 Both Feng Menglong and the Folksong Weekly editors included the "bawdy" and "vulgar" in their romanticized visions of folksongs and, by extension, the folk.

During the revolutionary period when Mao Zedong 毛泽东 was based in Yan'an 延安, the influential musicologist Lü Ji 吕瀷 reiterated the romantic view of the "folk" in his (1941) "Outline for Chinese folk music research" (Zhongguo minjian yinyue yanjiu tigang 中国民间音乐研究提纲) - one of the key theoretical texts used in the 1953 Hequ trip's methodological approach. ${ }^{26}$ Lü argued that licentious folksongs were not created by the "great masses" but by "a small number of idle urban scholars, men who visit prostitutes, and morally decrepit young hooligans from rich families." ${ }^{27} \mathrm{He}$ suggested that the people were simple-hearted, honest, sincere, and devoid of the slick articulation used by fallen scholars from the cities, and he pointed to northern Shaanxi folksongs as examples of authentic creations of the masses. ${ }^{28}$ We see a similar romantic view of the people in Mao Zedong's (1942) "Talks at the Yan'an conference on literature and art." While admitting "[t]he people ... have their shortcomings" and "backward ideas," Mao described a transformation in his thinking from when he "felt that intellectuals were the only clean people in the world, while in comparison workers and peasants were dirty" to his later view that "the workers and peasants were the cleanest people, and, even though their hands were soiled and their feet smeared

21 Hsu 2006, 78-79.

22 Translated in Yang, Shuhui 1998, 29.

23 Filene 2000, 10.

24 Lowry 1993, 96.

25 Translated in Hung 1985, 50.

26 Xiao 2007, 190.

27 Lü 1962, 375.

28 Lü 1962. 
with cow-dung, they were really cleaner than the bourgeois and petty-bourgeois intellectuals." 29 Both Lü and Mao refused to associate any moral "dirt" with the people.

Moral judgements continually played a part in these representations of the folk. How to conceptualize songs about illicit love was an important topic in May Fourth era scholarly works that examined the relation between folksongs and the oppression of women. Liu Jing'an's 刘经庵 (1928) Women in Folksongs and Yang Shiqing's 杨世清 (1928) “The position of Chinese women as seen through songs" both depicted women as victims of feudal society and suggested folksongs were the only means through which women could express their bitter situations. ${ }^{30}$ Liu and Yang argued that reformers could better understand existing social ills by analysing folksong lyrics. Liu's book organizes song lyrics into chapters corresponding to women's relationships with their parents, matchmakers, parents-in-law, sisters-in-law, husbands, sons, lovers, etc. with subsections such as "Parents despising their daughter," "Selling and marrying off their daughter," and "Beaten and scolded by the husband." 31 Liu's chapter arrangement appears to suggest that the oppression felt by women in the arranged marriage system drove them to seek solace in relationships with lovers. Later on, once again citing the victimization of women as evidence of the need for social change, Mao Zedong's "Decree regarding marriage" argued that women's "oppression and suffering" was much greater than men's and that the new Marriage Law, based on the principle of "free choice," would help women "to escape from their tragic circumstances." 32

After the establishment of the People's Republic of China in 1949, the new Marriage Law was promulgated on 1 May 1950, with the Land Reform Law following soon after on 2 June of the same year. ${ }^{33}$ The close timing of the two laws suggested that they were meant to act together: land reform would redistribute property and power within the scope of the villages, and marriage reform would do the same within families. ${ }^{34}$ However, the implementation of marriage reform was hampered by several concerns. Men feared losing their wives and half their land - both traditionally considered to be familial property - leading them to refer to the Marriage Law as the "woman's law" or the "divorce law." 35 Some believed that the Marriage Law might lead women towards libertine sexual behaviour. According to Neil J. Diamant, there was a "popular notion that freedom of marriage was little more than an invitation to promiscuity." 36 Others posited that the feudal marriage system would fall apart along with the feudal

29 Denton 1996, 460, 462.

30 Liu, Jing'an, 1971[1928]; Yang, Shiqing 1989[1928].

31 Liu, Jing'an, 1971[1928].

32 Diamant 2000, 179; Schram 1969, 337.

33 Meijer 1971, 69.

34 Johnson 1983, 102.

35 Ibid., 105; Meijer 1971, 125.

36 Diamant 2000, 171; Evans 1997, 84. 
economic system once land reform was completed, obviating the need to actively pursue changes in the marriage system. ${ }^{37}$ Nevertheless, the Marriage Law was described as a "weapon" that would help to "hasten the collapse and the death of the old feudal marriage system" and aid the development of the new society. ${ }^{38}$

While various campaigns to popularize and implement the Marriage Law were held from 1950 to 1953, Judith Stacey notes that each push tended "to coincide with the completion of land reform in a given locale." ${ }^{39}$ Scholars contend that in actual practice, the Marriage Law was essentially put on hold until land reform had been completed. ${ }^{40}$ By the spring of 1953, land reform had been largely realized. In March of that year, the prime minister, Zhou Enlai, called for a monthlong movement for the implementation of the Marriage Law. ${ }^{41}$ The movement stressed that marriage reform was not only a women's rights issue but also affected "national production and construction and the whole social order." 42 It argued that feudal marriages led to more quarrels and frustrations, which in turn led to less diligent labour, while democratic marriages tended to be more harmonious and led to more efficient labour. ${ }^{43}$

Divorce rates peaked as a result of the 1953 campaign for marriage reform, and adultery was considered to be one of the main reasons for divorce in the early 1950s. ${ }^{44}$ Kay Ann Johnson suggests the disruption caused by divorces was downplayed during the campaign, instead "emphasiz[ing] that the democratic reform of the family could be carried out without undermining basic, traditional aspirations for a secure family life." 45 The Hequ folksong collection trip was carried out against the backdrop of the promotion of the new Marriage Law and amid concerns about the social effects of adultery and divorce. Right in the middle of the collection trip, discussed more fully below, an 11 November 1953 report on the progress of the Marriage Law's implementation encouraged all levels of government and various organizations to "consider the work of implementing the Marriage Law as one of their constant tasks." 46 In what follows, I look at how this historical context appears to have influenced the analysis and representation of the collected songs.

\section{The 1953 Shanxi Folksong Collection Trip}

At the beginning of the 1950s, the State Cultural Bureau issued a call for "carrying on cultural heritage" and "developing traditions." This led to the

38 Quoted in Meijer 1971, 78.

39 Stacey 1983, 176; Johnson 1983, 98.

40 Johnson 1983, 101, 103; Stacey 1983, 176; Diamant 2000, 175.

41 Meijer 1971, 69, 303-06.

42 Ibid., 303.

43 Ibid., 308-09.

44 Johnson 1983, 147; Evans 1997, 196-97.

45 Johnson 1983, 147.

46 Meijer 1971, 312-13. 
establishment of music work groups (yinyue gongzuo zu 音乐工作组) in each province who were responsible for collecting and categorizing all types of Chinese traditional music. ${ }^{47}$ These groups organized local folksong collection activities in the majority of provinces and regions. Shen Qia cites the 1953 Hequ trip as one of the two most influential and representative examples of such endeavours during that period. ${ }^{48}$ The eminent folksong scholar Qiao Jianzhong also notes that the 1953 trip inspired many later projects. ${ }^{49}$

Armed with theory and methodology based on the preface to Mao Zedong's Rural Surveys (Nongcun diaocha xuyan 农村调查序言) and Lü Ji's “Outline for Chinese folk music research," the team's goal was "to understand the relationship between folksongs and people's lives through an in-depth collection of material in one area." ${ }^{50}$ From September to December of 1953, the researchers collected over 3,000 folksong lyrics, 149 of which were published together with academic articles in the book Hequ Folksongs: A Collection of Investigations and Research (Hequ minjian gequ: diaocha yanjiu zhuanji 河曲民间歌曲: 调查研究专辑, hereafter Hequ Folksongs). ${ }^{51}$ The team's "Outline of important points for research" urged collectors to "choose material with an ideological content, a positive meaning, and research value as a focal point, and [to] avoid enumerating phenomena without differentiating between good and bad." 52 Building on the idea of "transforming social traditions" (yifengyisu), Hequ Folksongs cited two reasons people choose to sing: (1) to praise pleasant aspects of life, and (2) to complain about unpleasant aspects: 53

From "The airs of the states" in The Book of Songs and the Han Dynasty Music Bureau (yuefu) all the way to recent folksongs, it is not hard for us to see there is a great majority reflecting the suffering of the people and singing the praises of the people's desires for happiness. Among Hequ folksongs, with regards to the question of why people want to sing, there are two explanations. One says, "Learn to sing to relax and improve one's mood." The other says, "Learn to sing to dispel one's sadness." Each of these sayings has its place, because when people are happy they sing optimistic songs; when people are depressed, they sing "sadness-dispelling" songs. Regardless of if they express optimism or dispel sadness, they all confirm the following principle: the reason people want to sing is because they have thoughts and feelings about the phenomena of social life, and precisely because they have those thoughts and feelings, then and only then do they have their means of expression. ${ }^{54}$

Within this conceptual framework, the researchers divided social life into what was "good" and as it should be, and what was "bad" and ought to be changed. The researchers' distinction between good and bad was aligned with the Marxist narrative of historical determinism - that is, negative aspects of society were linked to the "feudal" period before 1949 and positive features to the period

47 Qiao 1998, 327; Wang, Yaohua 1999, 10.

48 Wang, Yaohua 1999, 10; Shen 1999, 18.

49 Qiao 1998, 329.

50 Xiao 2007, 190; ZYXZYY 1962, 1.

51 There are 119 numbered songs containing lyrics and cipher notation for the melodies. In addition, there are 30 sets of song lyrics without musical notation.

52 ZYXZYY 1962, 139.

53 Yang, $\mathrm{Mu} 1994,113$.

54 ZYXZYY 1962, 12. 
afterwards. Within this historical narrative, the researchers portrayed folksong lyrics as "objective, honest" reflections of "all sorts of social phenomena within particular historical circumstances," making them privileged data for research. ${ }^{55}$

\section{Moral-Temporal Categorization}

In order to exhibit the "historical realities" before and after the founding of the People's Republic of China, the editors of Hequ Folksongs organized 149 songs into four categories that reflected different aspects of local life: class relations and economic life (48 songs); marital suffering of women in the old society (37 songs); love life between the sexes in the old society (60 songs); and praise for the new life after 1949 (4 songs). ${ }^{56}$ These four sections seem to paint a historical narrative complete with implicit value judgements - the first three sections deal with the characteristics of the old society and are implicitly critical, while the fourth attempts to reflect the state of the "new" society in a laudatory manner. In addition to condemning the old and praising the new, the ordering of these categories suggested that after land reform had improved economic conditions and class inequality (represented by the first section), marriage reform would improve the position of women in society and lead to more happy and productive couples (represented by the second section, and potentially the third, see below), all of which would result in new improved lives (represented by the fourth section). This narrative was further reiterated and made explicit in one of the analytical essays in a section of the book entitled "Hequ folksongs and the love lives of the Hequ people." The essay was organized into similar chronological subsections: "Old folksongs and painful marital lives," "Old folksongs and love life" (which describes extramarital relations as a "love tragedy brought on by the feudal marriage system"), and "New folksongs and happy marital lives." 57

Although the order of the categories in Hequ Songs suggested a progressive narrative from feudal past to improved present, the actual number of songs in each category problematized such a clear-cut account. To begin with, the team found few songs praising the "new life after 1949." 58 Lacking an abundance of praise for the new, they instead focused on criticism of the old, framing numerous song lyrics about "going beyond the Western Pass" (zou xikou 走西口) as an indictment of the old society. One of the essays in the latter half of the book looked at the effects of land distribution on peasants. Another problematizing factor was that the vast majority of collected songs were categorized under "love life between the sexes in the old society," and the team found a local phenomenon of extramarital relations "extremely common in Hequ, and reflected most in the folksongs." 59 This phenomenon, known as "making friends" (wei 
pengyou 为朋友) or “forming partnerships” ( $d a$ huoji 搭伙计), included extramarital affairs between married individuals as well as young people who had "married" without formal ceremonies and parents' approval, leading one scholar to call it “a type of illegal love” ( yi zhong bu hefa de lian'ai 一种不合法的恋爱), while another referred to it as "abnormal, illegal 'clandestine love affair' behaviour” (fei zhengchang de, bu hefa de touqing xingwei 不正常的、不合法的偷情行 为). ${ }^{60}$

Unlike issues of class struggle and land reform, the "forming partnerships" phenomenon proved more ideologically ambiguous, owing in part to its problematic relation to the 1950 Marriage Law. The new law called for "the free choice of partners," similar to what many "forming partnerships" lyrics appeared to suggest. ${ }^{61}$ In addition, the terms in the songs describing free choice and the mutual benefits involved in extramarital relations often came close to the language the law used to describe the newly proposed system of marriage based on individual choice. For example, “making friends" (jiao pengyou 交朋友 or wei pengyou) is a standard term for courtship leading to marriage and can also refer in certain local areas to extramarital or premarital relations. ${ }^{62}$ With regards to the former meaning, Evans notes, "The official discourse upheld courtship as an indispensable aspect of the free-choice model of marriage. Often known as 'making friends' (jiao pengyou), it was explained as the appropriate way for young people to develop the mutual understanding and affection considered necessary to realize the new model of conjugal marriage."63 Nevertheless, in some song lyrics, the relative merits of "making friends" are explicitly contrasted with those of marriage, suggesting that the two constitute mutually exclusive categories. ${ }^{64}$ In an interview with the author, one of the local collectors involved in the 1953 Hequ collection trip, Zhang Cunliang 张存亮, cited lyrics that imply that "making friends" (wei pengyou) was a last resort when one was financially unable to marry. ${ }^{65} \mathrm{He}$ also recited lyrics contrasting the transience and emptiness of "making friends" with the stability and rootedness of marriage. ${ }^{66}$ These multiple connotations of "making friends" point to an ambiguity of potential outcomes stemming from such "courtship."

Another term for extramarital relations, "forming partnerships" (da huoji), can also refer to forming a partnership with another person to do business. In the context of the song lyrics discussed here, however, "forming partnerships" refers to "cohabiting without marriage" and/or "non-marital" (fei hunyin 非婚姻)

60 Ibid., 122; He and Zhang 1956, 18; Li 2005, 105. Scholars define the terms in different ways, ranging

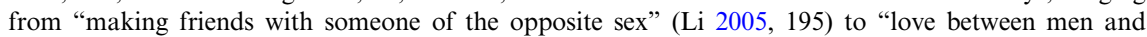
women" (He and Zhang 1956, 79; Chen 1982, 156) to "looking for a lover" (Wang, Kewen 1986, $15)$, in addition to the other definitions mentioned above.

61 Johnson 1983, 23.

62 Evans 1997, 84.

63 Ibid.

64 Cf. Cao 2004, Vol. 1, 1025.

65 Interview with Zhang Cunliang, Hequ, Shanxi province, 24 July 2010.

66 Ibid. 
relations between men and women. Once again, there is a striking overlap between this term and some of the language used in the Marriage Law. In a section of the law entitled "Rights and duties of husband and wife," Article 7 describes husband and wife as "companions living together." ${ }^{67}$ Article 8 states, in part, "Husband and wife are in duty bound to love, respect, assist and look after each other." 68 What to do, then, with song lyrics describing material benefits one can gain from forming relationships with men of different professions? Furthermore, what to do with lyrics vowing fidelity to one's lover until death, although that lover may be extramarital?

While love and mutual support were key components in the 1950 Marriage Law, the law also clearly stated that the "new democratic marriage system" was "based on ... monogamy," and that both "bigamy" and "concubinage" were expressly prohibited. ${ }^{69}$ Thus, while extramarital affairs could be (and were) portrayed as a form of popular resistance to the constraints imposed by the system of arranged marriage (which would be an indictment of the old society), the presence of song lyrics about women waiting for their husbands to die in order to marry their lovers undoubtedly would have resonated with men's fears regarding the newly established right to divorce. Seen in this light, certain aspects of "forming partnerships" lyrics highlight less desirable (from the perspective of men) aspects of the new law. However, as shown below, the way in which these songs were categorized and analysed attempted to resolve any potential ambiguity.

\section{Classifying the Morally Ambiguous}

Given the ambiguous overlaps between "forming partnerships" and language in the new Marriage Law, the Beijing researchers were forced to create a new sub-narrative incorporating the moral ambiguity of "making friends" into the transition from arranged marriage to free love. To do so, one of the team's main subgroups, the Love Life Research Group (aiqing shenghuo diaocha zu 爱 情生活调查组), set out to examine historical and contemporary circumstances of marriage in Hequ, focusing on three research topics: (1) suffering caused by the feudal marriage system; (2) "all types of phenomena involving "making friends' (wei pengyou) and 'forming partnerships' (da huoji)"; and (3) happy love lives brought by the new marriage system. ${ }^{70}$ Knowing that local people would be apprehensive about discussing such extramarital affairs openly, the Love Life Research Group chose to begin by researching "pain and suffering in marriage," which was seen as an easier topic to approach since "[t]he masses [had] relatively few misgivings in discussing them." 71 The research group

67 Johnson 1983, 236.

68 Ibid.

69 Ibid., 235.

70 ZYXZYY 1962, 122-23.

71 Ibid., 123. 
reasoned that they could find out about the "forming partnerships" phenomenon more easily after examining such suffering. ${ }^{72}$ While the exact process by which songs about "making friends" were elicited is not described, earlier in the report there is a description detailing how the collectors prompted performances of songs about "going beyond the Western Pass":

[W] invited six or seven women who had life experience and could sing. We asked them to remember life back then and to sing folksongs reflecting their feelings at that time. As soon as we asked them to do this, they became lost in thought, and couldn't help singing out. ${ }^{73}$

Based on this account, it seems possible that the songs about "pain and suffering in marriage" may have also been collected in a similar manner. By positioning extramarital affairs between the old and new, the researchers were essentially placing such affairs in a liminal period within the broader historical narrative, connected to both past and future but exclusive to neither.

In the team's final analysis, the Chinese Music Research Institute scholars categorized the local phenomenon of extramarital relations together with other social problems believed to have been caused by the old marriage system. The feudal marriage system, the group suggested, had constrained the Chinese people for several thousand years, causing pain and suffering in marriages and forcing people to "adopt irregular means of 'making friends' and 'forming partnerships' to satisfy the needs of their love lives." ${ }^{\prime} 7$ The team added that the new Marriage Law would allow people to begin to lead "normal, happy love lives." 75 In a footnote, they suggested that the causes behind the need for land reform and marriage reform were related. While emphasizing that the feudal marriage system was the main cause of extramarital affairs, the footnote added that the affairs were triggered by a combination of poverty and economic oppression (i.e. poor-quality land and landlord domination). Both factors, the team suggested, forced men to travel long distances to make a living "beyond the Pass" (i.e. to Inner Mongolia) and led married couples to experience extended periods of separation, causing feelings of emptiness and a lack of economic support for the wives left behind. Such a lack of support would lead, the researchers suggested, to "making friends" and "forming partnerships." 76

The team's analysis portrayed women involved in extramarital affairs as tragic figures oppressed by the constraints of arranged marriage and economic inequality. The authors credited the idea that these affairs were an "inevitable product of feudal society" and represented resistance against the oppression caused by that system to He Qifang's influential 1951 article, "On folksongs" (Lun min'ge 论民歌). ${ }^{77}$ In addition to the citation of He's article in Hequ Folksongs, the article and the anthology of northern Shaanxi folksongs in which it was first published

72 Ibid.

73 Ibid., 121.

74 Ibid., 169.

75 Ibid., 169-170.

76 Ibid., 169.

77 See footnote at the bottom of ZYXZYY 1962, 183. 
appear to have set a precedent for the tragic view of "making friends" and "forming partnerships" that is seen again and again in later studies from the early 1950s up through the 1980s. The anthology of northern Shaanxi folksongs, which was co-edited by He Qifang, includes a narrative song entitled "Forming partnerships" (Da huoji 打伙计). This song tells the story of a woman whose husband had run away at the age of 16 , forcing her to repeatedly "form partnerships" with different men. The men then abandoned her one by one, until she ended up dying alone. ${ }^{78}$ He Qifang wrote that the song was originally a "little ditty" (xiaodiao 小调) from Shanxi province that later became popular in northern Shaanxi. ${ }^{79}$ The seventh stanza reads,

上也无老靠,

下也无儿孝;

难得奴家无奈何,

才把伙计打。 80

Above me, I had no elders to depend on,

Below, I had no sons to be filial,

Faced with this difficult spot, I had no choice,

Only then did I "form partnerships."

This same stanza is quoted again in Chen Hongxin's 1982 analysis of traditional folksongs about "illicit love." 81 Wang Kewen's classic 1986 study of northern Shaanxi folksongs also includes a detailed description of the song's narrative, adding that the story "reveals the tragic fate of numerous labouring women in feudal society" (jieshi le fengjian shehui guangda laodong funü de beican mingyun 揭示了封建社会广大劳动妇女的悲惨命运). ${ }^{82}$ Each of these scholarly works quotes and/or paraphrases excerpts of song lyrics as evidence of the desperate situations that drove women to such affairs and the tragic ways in which those affairs ended. However, this tragic portrayal of "forming partnerships" was only one of several potential interpretations.

\section{The Light-hearted Side of "Making Friends"}

Although the scholarly articles in Hequ Folksongs emphasize the "tragic view" of "making friends," there are also song lyrics in the collection about how to keep one's affair a secret and outmanoeuvre jealous husbands. ${ }^{83}$ When looked at together with song lyrics from more recent anthologies, we find a range of light-hearted elements (for example, suggestions on how to choose a lover and implied connections between the songs and festive occasions), which problematize the tragic view of "forming partnerships" and "making friends."

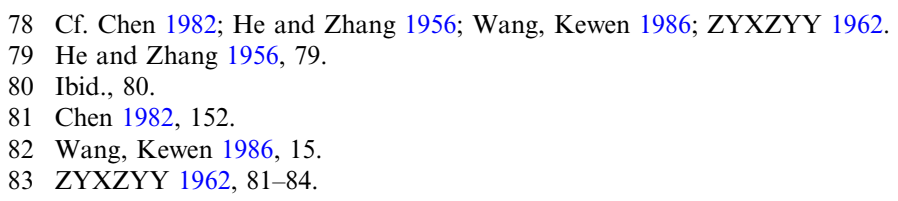


Many lyrics mention ideal ages for having such affairs, ranging from "fifteen or sixteen years old" to "over twenty." ${ }^{44}$ In addition to advice in the lyrics anthologized in Hequ Folksongs that discourage one from "making friends" with opium addicts and hoodlums, we find additional stanzas elsewhere urging against choosing soldiers and gamblers as lovers. ${ }^{85}$ These recommendations relate to a major theme of many of the song lyrics about "making friends" and "forming partnerships" in various anthologies - how to choose a suitable person as a lover. Often, advice on this matter is presented as a humorous provocation of social norms. In a version of "Making friends" from northern Shaanxi province that appears to have been sung back and forth between two singers at a drinking party for the entertainment of other guests, there are humorous guidelines for choosing a male lover ${ }^{86}$ After praising various regional liquors and encouraging the other guests to drink up, ostensibly to encourage the festive atmosphere, the singers debate the relative advantages and disadvantages of "making friends" with men of various professions. Amid playful banter, the singers consider the relative merits and drawbacks of each type of man. For example, shepherds bring their lovers delicious local fruits, but their onerous work schedules do not allow time for rendezvous. Coal miners, on the other hand, can share their large pay cheques but inevitably dirty one's mattress. Cadres, in turn, are "elegant and clean," but tend to be criticized as soon as they become well known. Drivers bring free rides and the delivery of coal to one's door. Scholars, although civilized in behaviour and conversation, merely affect a fake sense of refinement through the use of literary jargon. Other professions, such as bricklayer, blacksmith, carpenter, street cleaner and repairman, likewise come with perks, but these jobs have a tendency to be dirty and have a high predisposition towards occupational injury, including electrocution. In the end, the four professions deemed superior are hairdressers, tailors, cooks and interior decorators. ${ }^{87}$ Other professions and identities mentioned elsewhere include muleteers, shoemakers, bridal sedan bearers, wedding/funeral musicians (chuigushou 吹鼓手), Mongols, Hans, and male twins. ${ }^{88}$ As for men choosing female lovers, another song text categorizes women in terms of different hairstyles (totalling an impressive 14 varieties!), which are listed together with select brands of cigarettes and alcohol suitable for smoking and drinking. ${ }^{89}$

In addition to offering humorous advice on how to choose a lover, certain lyrics suggest that the "making friends" phenomenon was connected to festive occasions. The examples highlighted in bold below point to links between extramarital rendezvous, temple fairs, and house visits during the lunar New Year:

84 Yang, Cui 1995, 172, 176, 256; Cao 2004, Vol. 1, 638, 639, 988-89, 1025; Jia 2003, 14; Zhang 1987, Vol. $2,15$.

85 ZYXZYY 1962, 63; Zhang 1987, Vol. 2, 15; Cao 2004, Vol. 1, 650; Jia 2003, 14.

86 Ma 2004, 118-120.

87 Ibid.

88 Jia 2003, 53-54.

89 Cao 2004, Vol. 1, 1001-03. 
正月（就）里正月（就）正，我在（那就）你们家里串门门， 你有啥心来就我有啥意, 哎个哟哟, 咱们二人搭伙计。90

On the first day of the first lunar month, I come to your family's home to pay a visit,

Whatever you're thinking, I'm thinking it too, ai ge yo yo, let's "form a partnership" (da huoji).

正月十五秧歌排门子扭,

不知甚会儿想起个交朋友。91

On the 15th of the first lunar month (the Lantern Festival), the yangge dancers come from door to door,

I don't know at what moment, but it made me think of "making friends."

赶会看戏人烟多,

再不要戏场里撵断我。92

Going to temple fairs and watching plays, there are lots of people and smoke,

So, don't drive me away anymore when you see me in the theatre.

红火洒乐没几天,

不敢为朋友死心眼。93

Amid the revelry and pouring music, there are but a few days,

If you don't dare to "make friends," you are really closed-minded.

Recent ethnographic research has pointed to connections between singing at temple festivals and sexual relations. Frank Kouwenhoven and Antoinet Schimmelpenninck argue that mountain songs (shan'ge) form a widespread, pan-Chinese genre with local variations often performed at large temple festivals. $^{94}$ Kouwenhoven and Schimmelpenninck note that such songs, which would include those collected by the researchers in Hequ, offer flexible meanings. "They may be entertainment, but ... can also serve to establish sexual contacts." 95 In an earlier study, Yang $\mathrm{Mu}$ describes various "musical activities that are traditionally inseparable from local sexual customs" in his examination of "erotic musical activity" in different places and ethnic groups in China. ${ }^{96}$ The playful lyrics cited above resonate with Kouwenhoven and Schimmelpenninck's assertion that "temple festivals are a social space in which normal modes of behaviour may be turned upside down, and the shan'ge are the ideal vehicle to take action."97 Similar sorts of social inversions during festival times have been described earlier in northern Shaanxi, part of the same folksong-style region to which Hequ belongs. ${ }^{98}$ For example, David Holm, in his monograph on the 1940s Yangge movement in northern Shaanxi, notes that the New Year season was experienced as an extended "liminal period," and suggests that large-scale

90 Emus.cn. n.d. http://www.emus.cn/bbs/viewthread.php?action=printable\&tid=10041. Accessed 26 February 2010.

91 Cao 2004, Vol. 1, 1038.

92 Bden.cn. n.d. http://www.bden.cn/2007/whbd/ShowArticle.asp?ArticleID=780. Accessed 8 December 2008.

93 Bden.cn. n.d. http://www.bden.cn/2007/whbd/ShowArticle.asp?ArticleID=781. Accessed 8 December 2008.

94 Kouwenhoven and Schimmelpenninck 2013.

95 Ibid., 160.

96 Yang, Mu 1998, 199.

97 Kouwenhoven and Schimmelpenninck 2013, 163.

98 Northern Shaanxi and north-western Shanxi (including Hequ) are said to belong to the same "colour region" (secai qu) of folksong styles. See Miao and Qiao 1987. 
festival gatherings, such as temple festivals, were "[t]raditionally ... the occasion for sexual liaison between village youths and girls." "Such descriptions appear to problematize the tragic interpretation of "forming partnerships" put forward by the Hequ project scholars.

\section{Conclusion}

In a study of Ming dynasty and early Qing criticism of Chinese opera, Anders Hansson draws parallels between moral attacks on oral-connected and written genres - opera and popular fiction - suggesting that, "The most persistent criticism was concerned with 'licentiousness', i.e. stories about 'illicit' love and texts with sexual innuendo." 100 While written texts were supposed to "convey the Way" (wenyizaidao 文以载道), the opera libretti that Hansson discusses "were said to teach people immorality (quben hui ren yi yin 曲本诲人以淫).”101 Citing the work of Pierre Bourdieu, Sue Tuohy argues that classifying Chinese folksongs involves assertions made in "struggles about the meaning of the social world." 102 From Duke Zha to Feng Menglong to Lü Ji, the question of whether to view "licentious" songs in a positive or negative light is asked again and again, always in the context of praising or criticizing essentialized groups of people. Duke Zha used the "elaboration" of Zheng songs to criticize the kingdom's moral decay. ${ }^{103}$ Feng Menglong praised the "true love between man and woman" in local mountain songs to critique the "phoniness" of elite poetry and "the fake medicine of nominal rules." 104 The writers of Folksong Weekly's "Introductory note" sought a vibrant national literature that would encompass the folk, "bawdy" and all.

However, when the presence of "licentious" songs problematized scholars' assumptions about the people or highlighted contentious issues involved in the promotion of social agendas, scholars such as Lü Ji would search for ways to distance the songs from the people who sang them. The extramarital songs that the researchers from the Chinese Music Research Institute found in Hequ highlighted tensions between the new Marriage Law's promotion of free choice and Lü Ji's assertion of the people's moral purity. By positioning extramarital affairs in a liminal category between old and new, the researchers from Beijing set up a question: did this social phenomenon belong to the future or to the past? In the end, to maintain the people's "purity," both Lü Ji and the researchers found ways to distance the folk from the songs - Lü Ji by insisting that "licentious" songs originated from outside of the folk, and the writers of Hequ Folksongs by suggesting that the "forming partnerships" phenomenon was caused by poverty and the arranged marriage system. Rather than focusing on humorous lyrics

101 Here, I am drawing on Xiaobin Yang's $(2002,7)$ translation of wenyizaidao. Hansson 1998, $35,33$.

102 Tuohy 1999, 50; Bourdieu 1984, 479.

103 Cai 2002, 41.

104 Hsu 2006, 79 
that empowered women to choose their own lovers, the researchers tied "forming partnerships" to images of women as victims of feudal society, placing extramarital affairs with other remnants of the past. In this manner, by collecting and interpreting folksongs, the researchers were able to make the Hequ folk legible while at the same time seeking to transform them.

\title{
Biographical note
}

Levi S. Gibbs is assistant professor of Chinese language and literature at Dartmouth College. He is the author of Song King: Connecting People, Places, and Past in Contemporary China (University of Hawai'i Press, 2018).

\begin{abstract}
摘要: 在 1953 年贯彻 1950 年《中华人民共和国婚姻法》的过程中, 一批 来自中央音乐学院中国音乐研究所的研究员到山西省河曲县搜集民歌时, 遇到了大量关于婚外情的民间歌曲而将其解释为需要婚姻改革的证据。搜 集的歌词突出了《婚姻法》的有争议的方面, 拥护了《婚姻法》的中心原 则之一: 自由恋爱, 可也同时表达了女性离开丈夫的愿望。本篇文章探讨 研究人员如何将歌词放在 “封建” 婚姻与新婚姻制度之间的阈限道德时空类 别中, 然后才声称歌曲是妇女在过去的 “封建” 时代深受伤害的遗留物。作 者认为歌词当中附加的幽默元素使研究人员的结论复杂化, 并且表明, 当 20 世纪 40 年代和 50 年代促进社会变革的议程使得关于“打伙计”的民歌 被型塑为道德上模棱两可的时候, 当时的中国学者选择将民歌之“根”归于 本地老百姓“封建”的过去或者归于其他群体的影响, 而这些老百姓是他们 旨在歌颂和/或变革的。
\end{abstract}

关键词: 1950 年《婚姻法》; 婚外关系; 民歌; 婚姻改革; 山西; 河曲; 中国

\section{References}

Anderson, Benedict. 1991. Imagined Communities: Reflections on the Origin and Spread of Nationalism (revised ed.). London: Verso.

Bauman, Richard, and Charles L. Briggs. 1990. "Poetics and performance as critical perspectives on language and social life." Annual Review of Anthropology 19, 59-88.

Bourdieu, Pierre. 1984. Distinction: A Social Critique of the Judgment of Taste. (Richard Nice (trans.)). Cambridge: Harvard University Press.

Cai, Zong-Qi. 2002. Configurations of Comparative Poetics: Three Perspectives on Western and Chinese Literary Criticism. Honolulu: University of Hawai' i Press.

Cai, Zong-Qi. 2010. "Evolving practices of guan and Liu Xie's theory of literary interpretation." In Alan K.L. Chan and Yuet-Keung Lo (eds.), Interpretation and Literature in Early Medieval China. Albany, NY: State University of New York Press, 103-132.

Cao, Shiyu. 2004. Suide wenku - min'ge juan (Suide Library: Folksong Volume). Three vols. Beijing: Zhongguo wenshi chubanshe.

Chen, Hongxin. 1982. "Chuantong min'ge zhong 'siqing' ge neirong fenxi” (An analysis of the content of songs about "illicit love" among traditional folksongs). In Zhong Jingwen (ed.), Minjian wenyixue wencong (Collected Articles on Studies of Folk Art and Literature). Beijing: Beijing shifan daxue chubanshe, 142-156. 
Denton, Kirk A. (ed.). 1996. Modern Chinese Literary Thought: Writings on Literature, 1893-1945. Stanford, CA: Stanford University Press.

DeWoskin, Kenneth J. 1982. A Song for One or Two: Music and the Concept of Art in Early China. Ann Arbor, MI: Center for Chinese Studies, University of Michigan.

Diamant, Neil J. 2000. "Re-examining the impact of the 1950 Marriage Law: state improvisation, local initiative and rural family change." The China Quarterly 161, 171-198.

Evans, Harriet. 1997. Women and Sexuality in China: Female Sexuality and Gender since 1949. New York: Continuum.

Filene, Benjamin. 2000. Romancing the Folk: Public Memory \& American Roots Music. Chapel Hill, NC: University of North Carolina Press.

Fine, Elizabeth C. 1984. The Folklore Text: From Performance to Print. Bloomington, IN: Indiana University Press.

Frith, Simon. 2007. Taking Popular Music Seriously: Selected Essays. Hampshire: Ashgate.

Hansson, Anders. 1998. "What was wrong with Chinese opera?" CHIME Journal 12-13, 29-40.

Harker, Dave. 1985. Fakesong: The Manufacture of British "Folksong” 1700 to the Present Day. Milton Keynes: Open University Press.

He, Qifang, and Songru Zhang (eds.). 1956. Shaanbei min'ge xuan (Anthology of Northern Shaanxi Folksongs). Shanghai: Xin wenyi chubanshe.

Holm, David. 1991. Art and Ideology in Revolutionary China. Oxford: Clarendon Press.

Hsu, Pi-Ching. 2006. Beyond Eroticism: A Historian's Reading of Humor in Feng Menglong's Child's Folly. Lanham, MD: University Press of America.

Hung, Chang-tai. 1985. Going to the People: Chinese Intellectuals and Folk Literature. Cambridge, MA: Harvard University Press.

Jia, Deyi (ed.). 2003. Dahe, xikou, gudu: Hequ min'ge (Mighty River, Western Pass, Ancient Crossing: Hequ Folksongs). Taiyuan: Beiyue wenyi chubanshe.

Johnson, Kay Ann. 1983. Women, the Family and Peasant Revolution in China. Chicago: The University of Chicago Press.

Kouwenhoven, Frank, and Antoinet Schimmelpenninck. 2013. "I prefer a man who is fresh like a jumping fish': gender issues in shan'ge, Chinese popular rural song." In Rachel Harris, Rowan Pease and Shzr Ee Tan (eds.), Gender in Chinese Music. Rochester, NY: University of Rochester Press, 156-176.

Li, Xiongfei. 2005. Wenhua shiye xia de shan'ge rentong yu chayi: yi hezhou "hua'er" yu Shaanbei "xintianyou” bijiao wei ge'an (Cultural Similarities and Differences in Mountain Songs: A Case Study Comparing Hezhou Hua'er and Northern Shaanxi Xintianyou). Beijing: Minzu chubanshe.

Liu, Jing'an. 1971[1928]. Geyao yu funü (Women in Folksongs). Taibei: Dongfang wenhua shuju.

Liu, Lydia H. 2012. "Translingual folklore and folklorics in China." In Regina F. Bendix and Galit Hasan-Rokem (eds.), A Companion to Folklore. Malden, MA: Blackwell Publishing Ltd., 190-210.

Lowry, Kathryn A. 1993. "Feng Menglong's prefaces on currently popular songs." Papers in Chinese History 2, 94-119.

Lü, Ji. 1962. "Zhongguo minjian yinyue yanjiu tigang” (Outline for Chinese folk music research). In Zhongyang yinyue xueyuan Zhongguo yinyue yanjiusuo minzu yinyue yanjiu ban (ed.), Zhongguo xiandai yinyuejia lun minzu yinyue (Modern Chinese Musicians Discuss Chinese Traditional Music). Beijing: Zhongyang yinyue xueyuan Zhongguo yinyue yanjiusuo minzu yinyue yanjiu ban, 371378.

Lü, Ji. 2004. "Zhongguo minjian yinyue yanjiu tigang" (Outline for Chinese folk music research). In Lü Ji, Zhongguo chuantong yinyue yanjiu (Research on Chinese Traditional Music). Beijing: Zhongyang yinyue xueyuan chubanshe, 61-71.

Ma, Zhengchuan (ed.). 2004. Zhen xiang ni ya gege (Really Missing You, Older Brother). Beijing: Dazhong wenyi chubanshe. 
Meijer, M.J. 1971. Marriage Law and Policy in the Chinese People's Republic. Hong Kong: Hong Kong University Press.

Miao, Jing, and Jianzhong Qiao. 1987. Lun Hanzu min'ge jinsi secaiqu de huafen (On the Approximate Delineation of Han Nationality Folksong Colour Regions). Beijing: Wenhua yishu chubanshe.

Qiao, Jianzhong. 1998. Tudi yu ge (Songs of the Land in China). Jinan: Shandong wenyi chubanshe.

Schimmelpenninck, Antoinet. 1997. Chinese Folk Songs and Folk Singers: Shan'ge Traditions in Southern Jiangsu. Leiden: CHIME Foundation.

Schram, Stuart (ed.). 1969. The Political Thought of Mao Tse-tung. New York: Praeger.

Scott, James C. 1998. Seeing Like a State. New Haven, CT: Yale University Press.

Shen, Qia. 1999. "Ethnomusicology in China.” (Jonathan Stock (trans.)). Journal of Music in China 1 (1), 7-38.

Stacey, Judith. 1983. Patriarchy and Socialist Revolution in China. Berkeley, CA: University of California Press.

Tuohy, Sue. 1999. "The social life of genre: the dynamics of folksong in China." Asian Music 30(2), 39-86.

Tuohy, Sue. 2001. "The sonic dimensions of nationalism in modern China: musical representation and transformation." Ethnomusicology 45(1), 107-131.

Wang, Kewen. 1986. Shaanbei min'ge yishu chutan (A Preliminary Exploration of the Art of Northern Shaanxi Folksongs). Beijing: Zhongguo minjian wenyi chubanshe.

Wang, Yaohua. 1999. "Zhongguo chuantong yinyue yanjiu 50 nian zhi huigu yu sikao" (Review and thoughts on the research on China's traditional music in the past 50 years). Yinyue yanjiu 3, 10-16.

Wilgus, D.K. 1959. Anglo-American Folksong Scholarship since 1898. New Brunswick, NJ: Rutgers University Press.

Wilson, William A. 1973. "Herder, folklore and romantic nationalism." Journal of Popular Culture 6, 819-835.

Xiao, Mei. 2007. Zhongguo dalu 1900-1966: minzu yinyuexue shidi kaocha - biannian yu ge'an (Mainland China 1900-1966: Ethnomusicological Fieldwork - History and Case Studies). Shanghai: Shanghai yinyue xueyuan chubanshe.

Yang, Cui. 1995. Lushui dili chuan hongxie - xintianyou quji (Wearing Red Shoes on the Dew-covered Ground: A Collection of Xintianyou Pieces). Beijing: Renmin yinyue chubanshe.

Yang, Mu. 1994. "On the hua'er songs of north-western China." Yearbook for Traditional Music 26, $100-116$.

Yang, Mu. 1998. "Erotic musical activity in multiethnic China.” Ethnomusicology 42(2), 199-264.

Yang, Shiqing. 1989[1928]. "Cong geyao kan woguo funü de diwei” (The position of Chinese women as seen through songs). In Zhong Jingwen (ed.), Geyao lunji (A Collection of Articles on Folksongs). Shanghai: Shanghai wenyi chubanshe, 231-256.

Yang, Shuhui. 1998. Appropriation and Representation: Feng Menglong and the Chinese Vernacular Story. Ann Arbor, MI: Center for Chinese Studies, University of Michigan.

Yang, Xiaobin. 2002. The Chinese Postmodern: Trauma and Irony in Chinese Avant-Garde Fiction. Ann Arbor, MI: The University of Michigan Press.

Yang, Yinliu. 1980. Zhongguo gudai yinyue shigao (A Draft of the History of Ancient Chinese Music). Four vols. Beijing: Renmin yinyue chubanshe.

Zhang, Cunliang (ed.). 1987. Hequ geyao jicheng (Anthology of Hequ Songs). Two vols. Hequ, Shanxi: Hequ xian minjian wenxue jicheng bianweihui.

ZYXZYY (Zhongyang yinyue xueyuan Zhongguo yinyue yanjiusuo) (ed.). 1962. Hequ minjian gequ: diaocha yanjiu zhuanji (Hequ Folksongs: A Collection of Investigations and Research). Beijing: Yinyue chubanshe. 